\title{
METODE ISOLASI PYRICULARIA ORYZAE PENYEBAB PENYAKIT BLAS PADI
}

\author{
Danar Wicaksono ${ }^{1}$, Arif Wibowo ${ }^{2}$, \& Ani Widiastuti ${ }^{2}$ \\ ${ }^{1}$ Program Studi Fitopatologi, Fakultas Pertanian, Universitas Gadjah Mada \\ ${ }^{2}$ Departemen Hama dan Penyakit Tumbuhan, Fakultas Pertanian, Universitas Gadjah Mada \\ Bulak Sumur, Yogyakarta 55281 \\ Email: danar_wicaksono@mail.ugm.ac.id
}

\begin{abstract}
Isolation method of Pyricularia oryzae the causal agent of rice blast disease. Rice blast is a disease that reduces rice productivity and threatens global food reserves. The study of diversity and distribution of race fungal causing rice blast disease required a fungal isolates collection from different places and times. One of the challenges in collecting these fungi is the difficulty of isolation process. The purpose of this research was to study the proper isolation method of rice blast pathogen. The most appropriate isolation method of Pyricularia oryzae was to moisten the infected panicle, place on moist filter paper in a petri dish, and incubate plate for 2 days at room temperature under fluorescent lamp. Afterward, conidium was picked using sterile needle and transfered to potato dextrose agar without lactic acid.
\end{abstract}

Key words: isolation, Pyricularia oryzae, rice blast

\begin{abstract}
ABSTRAK
Metode isolasi Pyricularia oryzae penyebab penyakit blas padi. Penyakit blas padi merupakan salah satu penyakit yang dapat menurunkan produktivitas padi dan mengancam cadangan makanan global. Kajian mengenai keragaman dan distribusi ras jamur penyebab penyakit blas padi membutuhkan koleksi isolat jamur dari berbagai tempat dan waktu pengambilan. Salah satu kesulitan dalam mengumpulkan isolat jamur penyebab penyakit blas padi adalah proses isolasi. Tujuan penelitian ini adalah mengkaji metode isolasi jamur penyebab penyakit blas padi yang tepat. Metode isolasi jamur Pyricularia oryzae yang paling tepat adalah dengan melembapkan leher malai bergejala menggunakan kertas saring di dalam cawan petri, dan diinkubasi selama dua hari pada suhu ruang di bawah lampu TL. Setelah itu konidium P. oryzae diambil secara langsung menggunakan jarum dan ditumbuhkan pada media PDA tanpa asam laktat.
\end{abstract}

Kata kunci: isolasi, Pyricularia oryzae, penyakit blas

\section{PENDAHULUAN}

Penyakit blas padi merupakan salah satu penyakit yang dapat menurunkan produktivitas padi dan mengancam cadangan makanan global. Menurut Koutroubas et al. (2009), tanaman padi yang bergejala penyakit blas dengan intensitas tinggi akan mengalami penurunan bobot tanaman dan gabah. Menurut Hai et al. (2007), kehilangan hasil akibat penyakit blas terutama karena gejala patah leher berupa penurunan kuantitas gabah mencapai 38,2-64,57\%, kuantitas malai mencapai 3,12-11,27\%, dan bobot 1000 butir gabah mencapai 3,6 $-5,07 \%$.

Gejala penyakit blas pada daun padi dipengaruhi oleh kondisi lingkungan, umur tanaman, dan tingkat ketahanan tanaman (TeBeest et al., 2007). Gejala terdeteksi pertama kali pada fase medium tillering. Gejala awal dari penyakit ini adalah bintik putih atau hijau-keabu-abuan dengan tepi berwarna gelap kehijauan. Dalam perkembangannya gejala bintik tersebut berubah menjadi putih-kehijauan dengan tepi menunjukkan nekrotik berwarna cokelat-kemerahan. Sering kali gejala berbentuk oval dengan sisi runcing yang kadang bersudut sangat kecil dan kadang tidak terlalu kecil. Sisi runcing ini sejajar dengan pembuluh daun. Ketika terjadi sporulasi pusat dari bintik menjadi/ membentuk abu dan berwarna abu-abu karena keberadaan konidia dan hifa. Bagian tersebut memiliki panjang rata-rata $1 \mathrm{~cm}$ dan dapat mencapai panjang 3$4 \mathrm{~cm}$ pada jointing stage (Muñoz et al., 2007). Selain pada daun, gejala blas padi juga terjadi pada batang. Gejala penyakit blas padi pada batang dan malai berupa nekrotik berwarna cokelat tua (Gambar 1A) yang kadang dapat menghambat atau menghentikan aliran sap tanaman. Gejala pada ruas batang lebih sering terjadi dan lebih berbahaya dari pada gejala pada bagian antar 
ruas. Gejala pada ruas batang sering kali menyebabkan batang patah. Jamur pada ruas batang dapat bergeser mengikuti aliran embun menuju daun bendera dan menginfeksi lidah-lidah pada ketiak daun (ligula) (Gambar 1B). Infeksi pada ruas batang teratas (dasar malai) menyebabkan kerusakan yang sangat parah. Infeksi pada dasar malai menyebabkan penurunan bobot gabah dan dasar malai menjadi berwarna putih hingga malai tegak karena gabahnya kosong. Infeksi pada dasar dan cabang malai serta kerusakan pada leher malai dipengaruhi oleh keadaan lingkungan dan kultivar padi. Infeksi pada batang lebih sering terjadi pada saat fase pematangan bulir (Muñoz et al., 2007). Tantangan dalam pengelolaan penyakit blas adalah keragaman genetik jamur penyebab blas yang tinggi. Jamur penyebab penyakit blas padi diketahui mempunyai banyak ras fisiologi (Santoso \& Nasution, 2012). Setiap ras fisiologi memiliki sifat dan virulensi yang berbeda-beda (Semangun, 2008), sehingga memiliki tingkat ketahanan terhadap usaha pengelolaan penyakit tumbuhan yang berbeda-beda pula. Kajian mengenai keragaman dan distribusi ras jamur penyebab penyakit blas membutuhkan koleksi isolat jamur dari berbagai tempat dan waktu. Salah satu tantangan dalam mengumpulkan koleksi jamur penyebab penyakit blas padi adalah proses isolasi karena jamur penyebab penyakit blas sulit untuk diisolasi. Penelitian ini bertujuan untuk mengetahui metode isolasi yang tepat untuk mengisolasi jamur penyebab penyakit blas padi.

\section{METODE PENELITIAN}

Tempat dan Waktu. Penelitian ini dilakukan di Sub Laboratorium Klinik Kesehatan Tanaman, Departemen Hama dan Penyakit Tumbuhan, Fakultas Pertanian, Universitas Gadjah Mada, Yogyakarta pada bulan Juli 2015 hingga Mei 2016.
Pada penelitian ini dikaji tiga metode isolasi jamur penyebab penyakit blas dari tanaman padi. Metode isolasi dari suspensi spora dan leher malai disusun dengan mempertimbangkan hasil isolasi dari metode sebelumnya.

Metode Isolasi Umum. Metode isolasi umum merupakan modifikasi metode isolasi jamur patogen tanaman Mehrota \& Aggarwal (2003). Enam belas sampel daun padi bergejala blas yang digunakan dalam penelitian (Tabel 1).

Sampel daun tanaman padi bergejala blas dipotong kecil $\left( \pm 1 \mathrm{~cm}^{2}\right)$ lalu direndam kloroks $1 \%$ selama satu menit. Potongan daun bergejala tersebut kemudian direndam dalam air steril selama satu menit untuk membilas lalu ditiriskan. Setelah itu $5-6$ potongan sampel disusun pada media PDA (Potato Dextrose Agar) (PDA + 1 tetes asam laktat). Setelah beberapa hari, jamur yang tumbuh dimurnikan dan diidentifikasi menggunakan mikroskop.

Metode Isolasi dengan Suspensi Spora. Metode isolasi ini disusun berdasarkan modifikasi metode isolasi Tuite (1969), dan mempertimbangkan evalusi metode isolasi umum. Leher malai dan daun padi bergejala blas dari sampel PUR8.

Leher malai dan daun padi bergejala dipotong (7 $\mathrm{x} 0,5 \mathrm{~cm}$ ). Permukaan bagian tanaman bergejala dibersihkan dengan klorok dengan perendaman selama satu menit. Setelah itu dibilas dengan air steril selama satu menit. Jaringan tanaman tersebut lalu diinkubasi di atas tisu basah dalam cawan petri pada suhu ruang selama 1-2 hari. Setelah itu jaringan tanaman tersebut dipotong kecil dan direndam pada air steril. Leher malai dan daun direndam pada air steril secara terpisah. Sebelum dituang pada media buatan, suspensi diamati secara mikroskopi terlebih dahulu. Suspensi lalu dituang

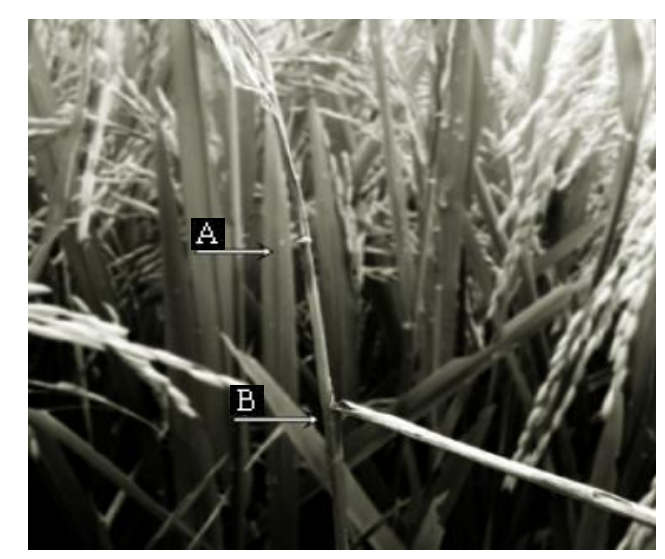

Gambar 1. Gejala penyakit blas padi; (A) pada ruas batang teratas (leher malai); (B) pada ketiak daun 
pada PDA (PDA + asam laktat) sebanyak $50 \mu 1$, kemudian diinkubasi selama satu malam. Konidium dipindahkan pada PDA baru hingga menjadi biakan murni lalu diidentifikasi.

Metode Isolasi dari Leher Malai. Metode isolasi dari leher malai disusun berdasarkan modifikasi metode isolasi Hayashi \& Fukuta (2009) dan mempertimbangkan evalusi metode isolasi dari suspensi spora. Leher malai padi bergejala blas dari sampel PUR8.

Leher malai bergejala dipotong melintang berukuran $7 \mathrm{~cm}$. Kemudian diinkubasi di atas tisu basah di dalam cawan petri tertutup (Gambar 2). Inkubasi dilakukan pada suhu ruang selama 1-2 hari dengan keadaan selalu terang. Konidia yang muncul dari permukaan jaringan tanaman kemudian diamati dengan mikroskop binokuler dan diambil dengan jarum jahit steril lalu dipindahkan pada PDA yang tidak mengandung asam laktat.

\section{Identifikasi Berdasarkan Ciri Morfologi.} Identifikasi berdasarkan ciri morfologi dilakukan menggunakan mikroskop. Biakan murni jamur hasil isolasi konidium tunggal dipotong kecil dan diletakkan pada gelas benda, kemudian ditambah lactophenol cotton blue, setelah itu dipanaskan di atas bunsen agar media PDA yang ikut serta dengannya mencair. Setelah media PDA mencair dan tidak panas, preparat ditutup

Tabel 1. Sampel yang digunakan pada isolasi metode umum

\begin{tabular}{llll}
\hline Sampel & Kabupaten & Provinsi & Varietas \\
\hline BAN2 & Bantul & DIY & IR64 \\
BANT2 & Bantul & DIY & - \\
BANU3 & Bantul & DIY & - \\
PUR4 & Ciamis & Jawa Barat & Ciherang \\
MAO1 & Cilacap & Jawa Tengah & Ciherang \\
NGR1 & Sragen & Jawa Tengah & - \\
GON1 & Sragen & Jawa Tengah & Ciherang \\
PED3 & Klaten & Jawa Tengah & IR64 \\
TAW3 & Sukoharjo & Jawa Tengah & IR64 \\
KES3 & Jombang & Jawa Timur & Ciherang \\
NGO3 & Jombang & Jawa Timur & IR64 \\
PET3 & Jombang & Jawa Timur & IR64 \\
JAM3 & Ponorogo & Jawa Timur & Ciherang \\
KAY3 & Kediri & Jawa Timur & Ciherang \\
PON3 & Malang & Jawa Timur & Ciherang \\
PONL3 & Malang & Jawa Timur & Ciherang \\
\hline
\end{tabular}

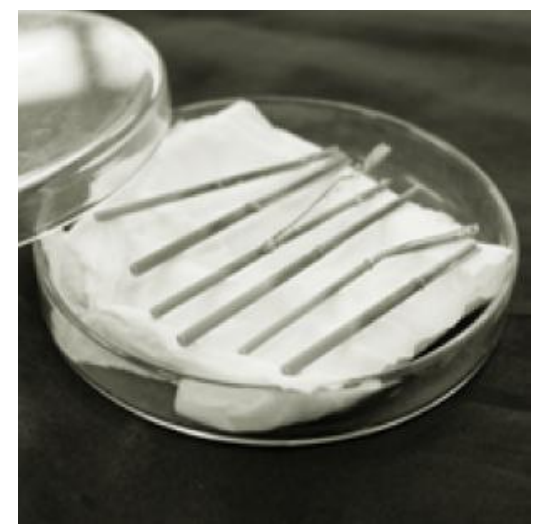

Gambar 2. Leher malai berukuran $7 \mathrm{~cm}$ bergejala blas di atas tisu basah di dalam cawan petri 
dengan gelas penutup. Kemudian diamati bentuk, warna, dan ukuran konidia Pyricularia oryzae dengan menggunakan mikroskop.

Identifikasi secara Molekuler. Identifikasi secara molekuler dilakukan untuk memastikan keberhasilan isolasi pada metode isolasi dari leher malai. Jamur hasil isolasi konidium tunggal ditumbuhkan pada $40 \mathrm{ml}$ media Potato Dextrose Broth (PDB) di dalam erlenmeyer. Kemudian miselium disaring dengan kertas saring pada corong. Kurang lebih 0,5 g miselium kering diletakkan pada mortal porselin lalu ditambahkan $700 \mu \mathrm{lCTAB} 2 \%$ dan pasir kuarsa secukupnya. Setelah itu digerus hingga benar-benar halus. Larutan tersebut lalu dipindahkan pada tabung (tube) 1,5 ml. Larutan dalam tube $1,5 \mathrm{ml}$ direbus pada air bersuhu $65{ }^{\circ} \mathrm{C}$ selama 30 menit dan digojog selama 1 menit dengan interval waktu 10 menit. Selanjutnya larutan disentrifugasi $5000 \mathrm{rpm}$ selama 5 menit. Supernatan dipindah pada tube $1,5 \mathrm{ml}$ baru kemudian ditambahkan CIAA hingga tube penuh pada batas 1,5 ml lalu gojog selama 1-3 menit. Setelah itu disentrifugasi 10.000 - $12.000 \mathrm{rpm}$ selama 10 menit hingga terbentuk tiga lapisan. Supernatan (larutan bagian paling atas) dipindah pada tube $1,5 \mathrm{ml}$ baru. Kemudian ditambahkan Etanol/alkohol absolut (alkohol 96\%) dingin hingga tube penuh pada batas $1,5 \mathrm{ml}$. Larutan lalu disimpan pada $-20{ }^{\circ} \mathrm{C}$ selama satu malam (4-8 jam).

Setelah itu larutan digojog hingga tercampur. Kemudian larutan disentrifugasi 10.000 - 12.000 rpm selama 10 menit hingga terbentuk pellet (endapan DNA). Alkohol (bagian atas) dibuang dan pellet dipertahankan di dasar tube. Kemudian ditambahkan alkohol $70 \%$ dingin hingga tube penuh pada batas $1,5 \mathrm{ml}$ lalu digojog 1-3 menit hingga pellet lepas dari dasar tube. Larutan kembali disentrifugasi 10.000 - $12.000 \mathrm{rpm}$ selama 10 menit. Alkohol (bagian atas) dibuang kembali dan pellet dipertahankan di dasar tube. Pellet pada dasar tube dikering angin menggunakan laminar air flow selama \pm 2 jam dalam keadaan tube terbuka. Setelah pellet kering ditambahkan 30-40 $\mu \mathrm{l}$ aquabides steril. Kemudian tube diketuk-ketuk hingga pellet DNA terlarut atau lepas dari dasar tube (Lestiyani, 2015).

Bahan yang digunakan dalam amplifikasi DNA adalah, aquabides steril 9,5 $\mu \mathrm{l}$, PCR master mix (KAPABIOSYSTEMS, Boston, Massachusetts) 12,5 $\mu \mathrm{l}$, Primer Forward ITS1 (5' - TCC GTA GGT GAA CCT GCG G - 3') $1 \mu$, Primer Reverse ITS4 (5' - TCC TCC GCT TAT TGA TAT GC - 3') $1 \mu$ l, dan DNA $1 \mu \mathrm{l}$ sehingga volume bahan amplifikasi DNA adalah $25 \mu$ l.

Amplifikasi dilakukan dengan program PraDenaturasi pada suhu $94{ }^{\circ} \mathrm{C}$ selama 5 menit; 40 siklus Denaturasi pada suhu $94{ }^{\circ} \mathrm{C}$ selama 1 menit, Annealing pada suhu $55^{\circ} \mathrm{C}$ selama 1 menit, dan Extention pada suhu $72^{\circ} \mathrm{C}$ selama 2 menit; dan Extention akhir pada suhu $72{ }^{\circ} \mathrm{C}$ selama 5 menit. Elektroforesis menggunakan $1 \%$ gel agarose dilakukan selama 45 menit pada 50 volt. Apabila pita DNA berada pada ukuran 550 bp maka proses identifikasi dilanjutkan dengan sequencing.

Tiga puluh mikroliter hasil amplifikasi dikirim kepada perusahaan penyedia jasa proses sequencing. Setelah itu hasil sequencing di cocokan dengan data GenBank menggunakan program BLAST pada website http://ncbi.nlm.nih.gov. Bila potongan nukleotida hasil sequncing cocok dengan potongan nukleotida Pyricularia oryzae yang tesimpan di GenBank maka sampel tersebut teridentifikasi sebagai $P$. oryzae.

\section{HASIL DAN PEMBAHASAN}

Metode Isolasi Umum. Isolasi jamur dengan metode isolasi umum dilakukan menggunakan beberapa sampel daun tanaman padi begejala blas (Tabel 1). Pada isolasi jamur dengan metode ini diperoleh beberapa jenis jamur yang beragam. Hal ini dikarenakan metode isolasi ini memungkinkan jamur-jamur endofit yang berada di dalam jaringan daun tanaman padi untuk tumbuh pada media PDA yang digunakan. Menururt Ariyanto et al. (2013), jamur endofit yang terdapat pada daun padi antara lain Aspergillus sp., Penicillium sp., Nigrospora sp., Trichoderma sp., Curvularia sp., Mucor sp., Mastigosporium sp., Alternaria sp., Fusarium sp., dan Monosporium sp., Verticillium sp. dan Acremonium sp..

Hasil identifikasi berdasarkan ciri morfologi mikroskopis menunjukkan bahwa kebanyakan isolat yang diisolasi merupakan jenis jamur Curvularia sp., Nigrospora sp. dan beberapa tidak teridentifikasi karena tidak membentuk konidia (Tabel 2 \& Gambar 3). Sunariasih et al. (2014), menunjukkan bahwa jamurjamur endofit dari biji padi memiliki daya hambat yang besar pada $P$. oryzae, sehingga diduga jamur endofit dalam proses isolasi ini mampu menghambat pertumbuhan $P$. oryzae.

Metode Isolasi dengan Suspensi Spora. Isolasi jamur penyebab gejala bercak seperti $P$. oryzae sebaiknya diawali dengan induksi spora. Proses ini menyebabkan jamur yang ada pada jaringan tersebut termasuk jamur $P$. oryzae akan membentuk miselium dan/atau konidia (Tuite, 1969). Pada metode ini proses isolasi diawali dengan induksi konidia. Proses induksi konidia dilakukan dengan cara melembapkan jaringan tanaman bergejala. Menurut Shurtleff \& Averre (1997), Setelah jaringan tanaman bergejala dilembabkan, konidia 
yang terbentuk pada permukaan jaringan dapat diamati dengan memotong kecil jaringan bergejala tersebut kemudian melarutkannya pada air steril. Konidia yang terlarut dalam air steril diamati menggunakan mikroskop binokuler (Gambar 4).

Pengamatan mikroskopi terhadap suspensi daun dan leher malai tanaman padi bergejala blas yang telah dilembapkan menunjukkan bahwa tidak terdapat konidia $P$. oryzae pada suspensi daun (Gambar 5A). Konidia $P$. oryzae tampak pada suspensi leher malai (Gambar 5B). Gambar 5 menunjukkan bahwa proses induksi konidia $P$. oryzae dari jaringan tanaman bergejala hanya dapat dilakukan dengan menggunakan sampel berupa leher malai.

Hasil yang diperoleh dari beberapa kali isolasi dengan metode ini adalah jenis jamur Fusarium sp. dan selebihnya koloni jamur tidak tumbuh. Fusarium sp. tumbuh karena pada suspensi yang dituang tidak hanya berisi konidium $P$. oryzae. Dalam proses pengambilan konidium $P$. oryzae konidium lain dapat terikut. Hal ini dapat diatasi dengan mengencerkan suspensi atau mengambil langsung konidium $P$. oryzae dari malai yang telah dilembapkan. Koloni jamur tidak tumbuh dapat dikarenakan oleh konidia tidak berkecambah. Konidia

Tabel 2. Jenis jamur yang teridentifikasi dari hasil isolasi dengan metode umum

\begin{tabular}{crll}
\hline Sampel & \multicolumn{2}{c}{ Isolat } & \multicolumn{1}{c}{ Jenis } \\
\hline BAN2 & BAN2 -2 & Nigrospora sp. \\
BANT2 & BANT2 -1 & Tidak teridentifikasi \\
BANU3 & BANU3 -1 & Nigrospora sp. \\
PUR4 & PUR4 -1 & Tidak teridentifikasi \\
PUR4 & PUR4 -2 & Nigrospora sp. \\
MAO1 & MAO1 -2 & Curvularia sp. \\
NGR1 & NGR1 -1 & Tidak teridentifikasi \\
GON1 & GON1 -2 & Tidak teridentifikasi \\
PED3 & PED3 -2 & Tidak teridentifikasi \\
TAW3 & TAW3 -1 & Curvularia sp. \\
KES3 & KES3 -1 & Curvularia sp. \\
NGO3 & NGO3 -1 & Curvularia sp. \\
NGO3 & NGO3 -2 & Curvularia sp. \\
PET3 & PET3 -2 & Tidak teridentifikasi \\
JAM3 & JAM3 -1 & Nigrospora sp. \\
KAY3 & KAY3 -2 & Nigrospora sp. \\
PON3 & PON3 -2 & Nigrospora sp. \\
PONL3 & PONL3 -1 & Nigrospora sp. \\
\hline & & &
\end{tabular}
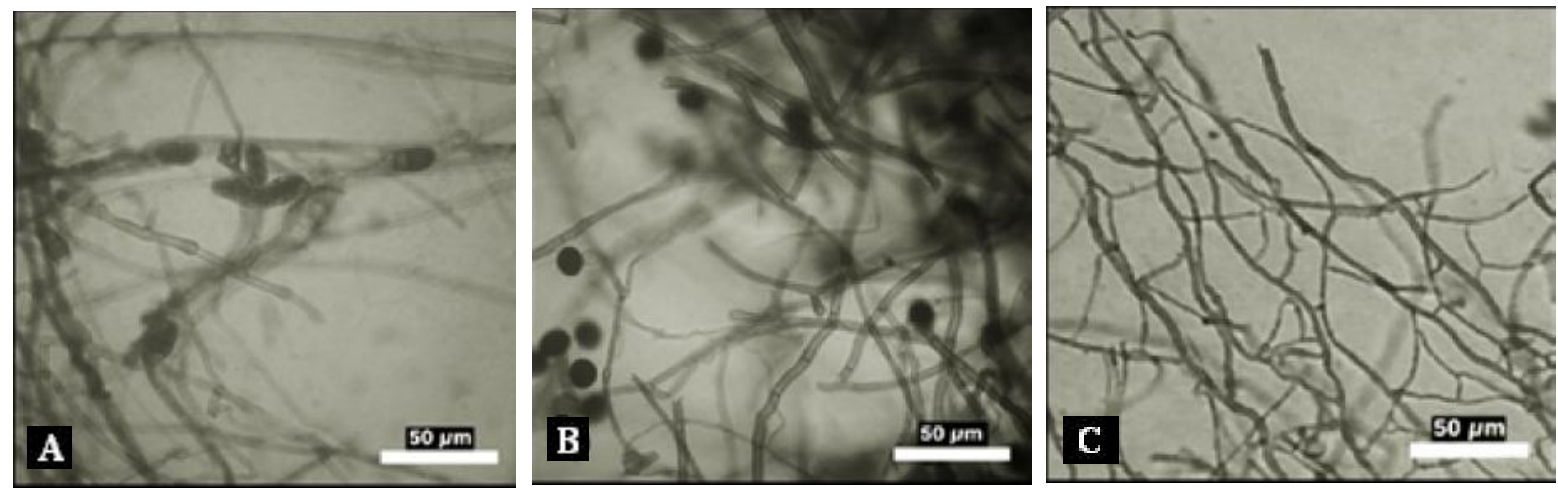

Gambar 3. Spora Nigrospora sp. pada sampel MAO1 (A), Nigrospora sp. pada sampel PON3 (B), dan miselia tanpa ciri morfologi pada sampel GON1(C) 
tidak berkecambah dapat disebabkan oleh keadaan media yang asam karena penambahan asam laktat. Metode ini dapat disempurnakan dengan mencoba untuk tidak mencampurkan asam laktat pada media PDA yang digunakan.

Metode Isolasi dari Leher Malai. Isolasi dari leher malai menghasilkan koloni jamur. Koloni jamur yang diperoleh merupakan biakan murni karena tumbuh dari konidium tunggal yang diambil langsung dari bagian tanaman bergejala yang telah dilembapkan. Namun koloni tersebut tidak membentuk ciri morfologi seperti konidium sehingga tidak dapat diidentifikasi secara morfologi. Koloni jamur yang diperoleh dimungkinkan berjenis $P$. oryzae karena koloni tersebut tumbuh dari konidium tunggal $P$. oryzae.

Identifikasi secara molekuler dilakukan untuk memastikan jenis jamur dari koloni yang telah ditemukan. Hasil amplifikasi menggunakan primer ITS1 dan ITS4 menunjukkan pita DNA pada jenjang $\pm 550 \mathrm{bp}$ (Gambar 6). Hasil sequencing dan mencocokan dengan GenBank menunjukkan bahwa isolat tersebut memiliki kemiripan sebesar 99\% dengan Magnaporthe oryzae [telemorph] Pyricularia oryzae [anamorph].

Morfologi koloni $P$. oryzae yang diperoleh berwarna hitam keabu-abuan, berbentuk tipis tanpa miselium udara, membentuk lingkaran menyerupai cincin setelah tumbuh hampir memenuhi cawan petri dalam media PDA (Gambar 7). Namun morfologi koloni $P$. oryzae dimungkinkan beragam sehingga dapat berbeda dengan isolat yang diperoleh pada metode ini.

Metode isolasi dari leher malai dipilih sebagai metode terbaik karena berhasil mengisolasi $P$. oryzae dengan proses yang paling singkat dan sederhana. Metode ini menghasilkan isolat akhir yang murni karena tumbuh dari konidium tunggal. Metode ini memiliki kelemahan berupa jenis sampel jaringan tanaman yang dapat digunakan hanya leher malai. Identifikasi pun harus dilakukan secara molekuler sehingga membutuhkan waktu dan biaya tambahan. Hal ini menjadi kendala apabila jumlah sampel yang diisolasi banyak.

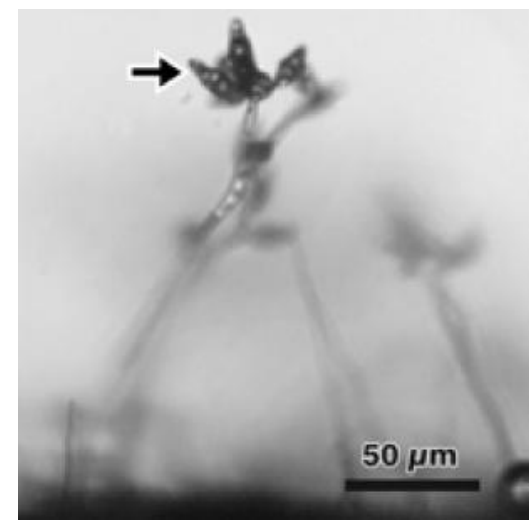

Gambar 4. Konidia Pyricularia oryzae yang tumbuh dari leher malai padi bergejala setelah dilembapkan
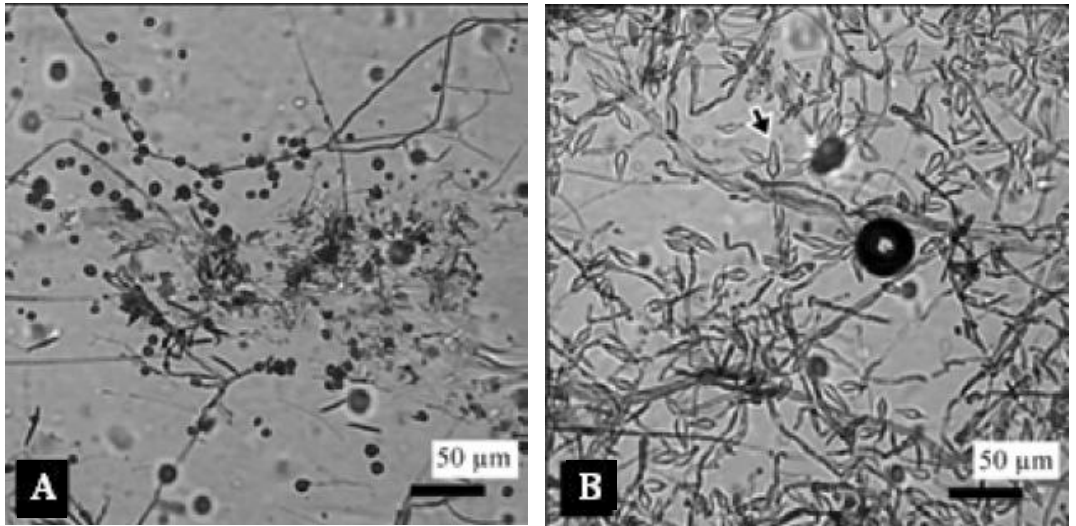

Gambar 5. Suspensi konidium dari daun padi bergejala blas, tidak ditemukan konidium Pyricularia oryzae (A) dan leher malai padi bergejala blas, ditemukan konidium Pyricularia oryzae (B) 


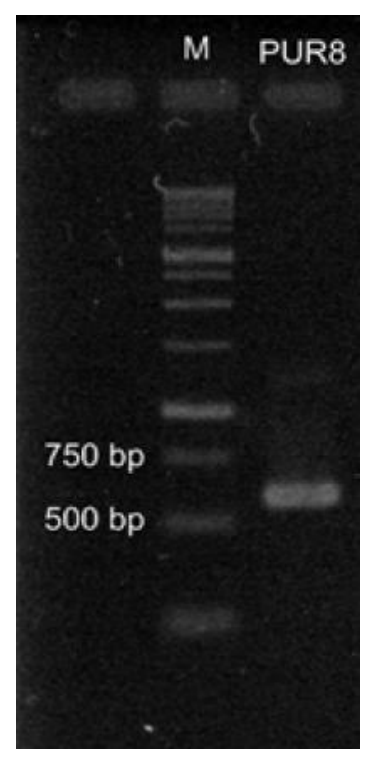

Gambar 6. Hasil elektroforesis setelah amplifikasi menggunakan primer ITS1 dan ITS4 pada sampel PUR8 hasil isolasi menggunakan metode isolasi dari leher malai, menggunakan $1 \%$ agarose gel. M: Marker (100, $200,300,400,500,600,700,800,900,1000,1500,3000)$
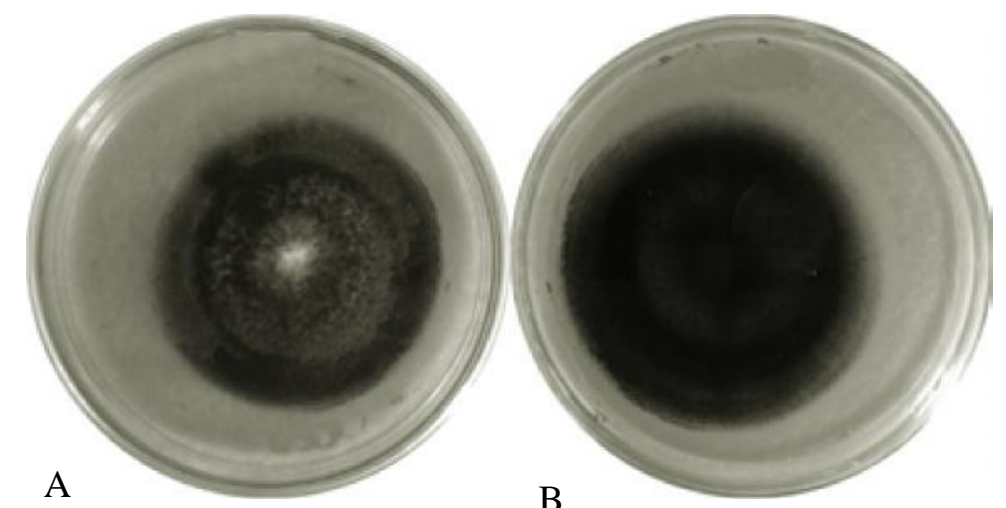

Gambar 7. Koloni Pyricularia oryzae pada media PDA; Tampak atas (A); tampak bawah (B)

\section{SIMPULAN}

Metode isolasi jamur P. oryzae yang paling tepat adalah dengan melembapkan leher malai bergejala selama dua hari penuh cahaya, lalu konidium $P$. oryzae diambil secara langsung menggunakan jarum dan diisolasi pada media PDA tanpa asam laktat.

\section{SANWACANA}

Terima kasih kepada Program Studi Fitopatologi dan Departeman Hama dan Penyakit Tumbuhan, Fakultas Pertanian, Universitas Gadjah Mada dan seluruh rekan-rekan yang membantu dan mendukung penelitian ini.

\section{DAFTAR PUSTAKA}

Ariyanto EF, Abadi AL, \& Djauhari S. 2013. Keanekaragaman jamur saprofit pada daun tanaman padi (Oryza sativa L.) dengan sistem pengelolaan hama terpadu (PHT) dan konvensional di Desa Bayem, Kecamatan Kasembon, Kabupaten Malang. Jurnal HPT 1(2): 37-51.

Hai LH, Kim PV, Du PV, Thuy TTT, \& Thanh DN. 2007. Grain yield and grain-milling quality as affected by rice blast disease (Pyricularia grisea), at My Thanh Nam, Cai Lay, Tien Giang. Omonrice 15: 102-107. 
Hayashi N \& Fukuta Y. 2009. Proposal for a new international system of differentiating races of blast (Pyricularia oryzae Cavara) by using LTH monogenic lines in rice (Oryza sativa L.). JIRCAS Working Report 63: 11-15.

Koutroubas SD, Katsantonis D, Ntanos DA, \& Lupotto E. 2009. Blas disease influence on agronomic and quality traits of rice varieties under Mediterranean conditions. Turk. J. Agric. for Forestry 33: 487494.

Lestiyani A. 2015. Identifikasi, Patogenisitas, dan Variabilitas Penyebab Penyakit Moler pada Bawang Merah. Tesis. Universitas Gadjah Mada.

Mehrota RS \& Aggarwal A. 2003. Plant Pathology. Tata McGraw-Hill Publishing Company Limited, New Delhi.

Muñoz MC, Álvarez IL, \& Aguliar M. 2007. Resistance of rice cultivars to Pyricularia oryzae in Southern Spain. Spain. J. Agric. Res. 5(1): 5966.
Santoso \& Nasution A. 2012. Pengendalian Penyakit Blas dan Penyakit Cendawan Lainnya. Balai Besar Penelitian Tanaman Padi, Jawa Barat.

Semangun H. 2008. Penyakit-Penyakit Tanaman Pangan di Indonesia. Gadjah Mada University Press, Yogyakarta.

Shurtleff MC \& Averre III CW. 1997. The Plant Disease Clinic and Field Diagnosis of Abiotic Disease. The American Phytopathological Society Press, Minnesota.

Sunariasih NPL, Suada IS, \& Suniti NW. 2014. Identifikasi jamur endofit dari biji padi dan uji daya hambatnya terhadap Pyricularia oryzae Cav. secara in vitro. E-Jurnal Agroekoteknologi Tropika. 3(2): 51-60.

TeBeest DO, Guerber C, \& Ditmore M. 2007. Rice Blast. http://www.apsnet.org /edcenter/intropp/ lessons/fungi/ascomycetes/Pages/ RiceBlast.aspx>. Diakses 21 Januari 2015.

Tuite J. 1969. Plant Pathological Methods. Burgess Publishing Company, Minneapolis. 